Atmos. Chem. Phys., 13, 7023-7037, 2013

www.atmos-chem-phys.net/13/7023/2013/

doi:10.5194/acp-13-7023-2013

(C) Author(s) 2013. CC Attribution 3.0 License.

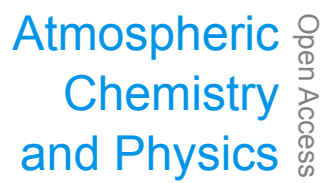

cC) (i)

\title{
Model calculated global, regional and megacity premature mortality due to air pollution
}

\author{
J. Lelieveld ${ }^{1,2}$, C. Barlas ${ }^{1}$, D. Giannadaki ${ }^{1}$, and A. Pozzer ${ }^{1,2}$ \\ ${ }^{1}$ The Cyprus Institute, Nicosia, Cyprus \\ ${ }^{2}$ Max Planck Institute for Chemistry, Mainz, Germany \\ Correspondence to: J. Lelieveld (jos.lelieveld@mpic.de)
}

Received: 19 February 2013 - Published in Atmos. Chem. Phys. Discuss.: 21 March 2013

Revised: 14 June 2013 - Accepted: 23 June 2013 - Published: 24 July 2013

\begin{abstract}
Air pollution by fine particulate matter $\left(\mathrm{PM}_{2.5}\right)$ and ozone $\left(\mathrm{O}_{3}\right)$ has increased strongly with industrialization and urbanization. We estimate the premature mortality rates and the years of human life lost (YLL) caused by anthropogenic $\mathrm{PM}_{2.5}$ and $\mathrm{O}_{3}$ in 2005 for epidemiological regions defined by the World Health Organization (WHO). This is based upon high-resolution global model calculations that resolve urban and industrial regions in greater detail compared to previous work. Results indicate that $69 \%$ of the global population is exposed to an annual mean anthropogenic $\mathrm{PM}_{2.5}$ concentration of $>10 \mu \mathrm{g} \mathrm{m}^{-3}$ (WHO guideline) and $33 \%$ to $>25 \mu \mathrm{g} \mathrm{m}^{-3}$ (EU directive). We applied an epidemiological health impact function and find that especially in large countries with extensive suburban and rural populations, air pollution-induced mortality rates have been underestimated given that previous studies largely focused on the urban environment. We calculate a global respiratory mortality of about 773 thousand/year (YLL $\approx 5.2$ million/year), 186 thousand/year by lung cancer $(\mathrm{YLL} \approx 1.7$ million/year) and 2.0 million/year by cardiovascular disease (YLL $\approx 14.3$ million/year). The global mean per capita mortality caused by air pollution is about $0.1 \% \mathrm{yr}^{-1}$. The highest premature mortality rates are found in the Southeast Asia and Western Pacific regions (about $25 \%$ and $46 \%$ of the global rate, respectively) where more than a dozen of the most highly polluted megacities are located.
\end{abstract}

\section{Introduction}

Air pollution has intensified strongly since the industrial revolution, i.e., during the period known as the Anthropocene (Crutzen, 2002). Estimates of pollution emissions, satellite observations, measurement data from monitoring networks and model calculations unambiguously show that air quality has degraded on regional and global scales (Akimoto, 2003; Anenberg et al., 2010; Lelieveld and Dentener, 2000; Saikawa et al., 2009; Van Donkelaar et al., 2010; Wang and Mauzerall, 2006). In parallel, evidence that air pollutants adversely impact human health, based on epidemiological studies, is mounting (e.g., Dockery et al., 1993; Pope et al., 1995, 2002; Samet et al., 2000; Brunekreef and Holgate, 2002; Bell and Domenici, 2008; Franck et al., 2011; Solomon et al., 2011).

Ozone $\left(\mathrm{O}_{3}\right)$ and particulate matter with an aerodynamic diameter smaller than $2.5 \mu \mathrm{m}\left(\mathrm{PM}_{2.5}\right)$ are two major contributors to hazardous air pollution with serious health impacts by cardiovascular and respiratory disease and lung cancer, and their long-term exposure has been associated with an increased risk of mortality (e.g., Laden et al., 2006; Krewski et al., 2009; Jerrett et al., 2009; Pellucchi et al., 2009; Pope et al., 2009; Brook et al., 2010; Lim et al., 2012; Lepeule et al., 2012). Unfortunately, in many parts of the world epidemiological studies and $\mathrm{PM}_{2.5}$ and $\mathrm{O}_{3}$ concentration data are lacking. To nevertheless obtain an overview of the global health impacts by air pollution, it is important to consistently include all regions in a comparative air quality analysis. Such information on the numbers of lives lost due to $\mathrm{PM}_{2.5}$ and $\mathrm{O}_{3}$ pollution is indispensable for public health planners and policymakers. 
Here we assess the premature deaths caused by anthropogenic $\mathrm{PM}_{2.5}$ and $\mathrm{O}_{3}$ pollution for the global population of $30 \mathrm{yr}$ and older in 2005, using a global atmospheric chemistry-general circulation model and applying a health impact function. We follow the approach of West et al. (2006) and Anenberg et al. (2010), who applied an atmospheric chemistry-transport model to assess human health impacts, though at relatively course resolution $\left(\sim 3^{\circ}\right.$ latitude and longitude), and estimated the global mortality due to anthropogenic air pollution for the year 2000 .

In the present study, we compute the global burden of premature human mortality for 2005 , using updated emission and population data and a higher resolution model $\left(\sim 1.1^{\circ}\right.$ latitude and longitude), so that urban and industrial regions are better resolved. Furthermore, we address regional and national impacts of air quality degradation to compare and categorize the mortality rates as well as the associated years of life lost by air pollution in different countries and major urban centers (megacities). Next the methodology and the data sources are presented (Sect. 2), followed by the results and their explanation (Sect. 3), an uncertainty analysis (Sect. 4), comparison with previous work (Sect. 5) and the conclusions (Sect. 6).

\section{Methods}

The global, annual premature mortality due to anthropogenic $\mathrm{PM}_{2.5}$ and $\mathrm{O}_{3}$ concentrations in 2005 , relative to unpolluted, preindustrial conditions, has been estimated by employing a human health impact function (Cohen et al., 2004) also used by Anenberg et al. (2010):

$\Delta$ Mort $=y_{0}[1-\exp (-\beta \Delta X)]$ Pop,

where $\Delta$ Mort is the change in annual mortality due to a given pollutant; $y_{0}$ is the baseline mortality rate (BMR) for a given population; $\beta$ is the concentration-response function (CRF) for the selected pollutants; $\Delta X$ is the change in concentration of pollutant $X$ (from the preindustrial level to the year 2005); and Pop is the total population with an age of $\geq 30 \mathrm{yr}$ exposed to the particular pollutant (abbreviations and acronyms are listed in Appendix A). Some studies apply Eq. (1) to the ambient $\mathrm{PM}_{2.5}$ concentration and subtract a threshold level (e.g., $7.5 \mu \mathrm{g} \mathrm{m}^{-3}$ ) below which no health effects are assumed (e.g., Cohen et al., 2004, 2005). Here we do not apply such a threshold because $\Delta X$ refers to the $\mathrm{PM}_{2.5}$ levels in polluted air relative to pristine, preindustrial conditions hence representing the anthropogenic pollution increment.

BMR data, described as the number of deaths in a particular year for a given population, were obtained from the World Health Organization (WHO) Statistical Information System on the country-level (WHO, 2012) based on the International Classification of Diseases 10th Revision (ICD10) classification system for different types of mortality. The range of ICD-10 codes used for cardiovascular, lung cancer, and respiratory mortality are the codes I00-I99, C33-C34 and J00-J99, respectively. Data were obtained at the country level where available, and if unavailable, the appropriate WHO regional level BMR data were used for each country. Country level data were used for 36 countries and regional data were assigned to 195 countries. It should be emphasized that $\Delta$ Mort scales linearly with $y_{0}$ (Eq. 1 ), so that countries and regions with relatively high baseline mortality rates are calculated to have proportionally higher excess mortality due to air pollution.

The CRF describes the increased risk of a population associated with a certain health response when exposed to a particular pollutant. In this study, the CRF has been derived from the relationship between the change in pollutant concentration and the relative risk (RR) of health impacts, as established in epidemiological cohort studies and given by the function

$\mathrm{RR}=\exp (\beta \Delta X)$.

The RRs from the epidemiological studies by Krewski et al. (2009) and Jerrett et al. (2009) were used as the CRFs for $\mathrm{PM}_{2.5}$ and $\mathrm{O}_{3}$, respectively. Both studies use data from the American Cancer Society (ACS) Cancer Prevention Study II (CPS-II) cohort, which includes participants who were at least $30 \mathrm{yr}$ in age at the time of enrollment (Pope et al., 2002).

The study by Krewski et al. (2009) is an extended analysis of the ACS CPS-II cohort, providing estimates of mortality risks in the United States from various causes with improved statistical methods, and for a longer follow-up period relative to previous analyses (Krewski et al., 2000a, b). Results of RR for $\mathrm{PM}_{2.5}$ were taken from the analysis performed for the years 1999-2000, using a random effects standard Cox model adjusted for 44 individual-level and seven ecologic covariates. The resulting mortality risk for cardiopulmonary disease (CPD) is $\mathrm{RR}=1.129$ for a $10 \mu \mathrm{g} \mathrm{m}^{-3}$ increase of $\mathrm{PM}_{2.5}$, giving rise to a $\mathrm{CRF}=0.012133$. Note that we apply this factor to cardiovascular disease (CVD) since the majority of premature mortality related to $\mathrm{PM}_{2.5}$ is caused by CVD rather than effects on the lungs. The discrepancy introduced by this assumption appears to be minor, which will be discussed in Sect. 4 . The lung cancer mortality risk $R R=1.137$ for a $10 \mu \mathrm{g} \mathrm{m}^{-3}$ increase of $\mathrm{PM}_{2.5}$, with a $\mathrm{CRF}=0.012839$. The $95 \%$ confidence intervals (CI) are also reported. For example, an increase of $10 \mu \mathrm{g} \mathrm{m}^{-3}$ in the concentration of $\mathrm{PM}_{2.5}$ is associated with an increase of $12.9 \%$ (95\% CI: 9.5-16.4\%) in CVD and $13.7 \%$ (95\% CI: $5.6-22.5 \%$ ) in lung cancer mortality.

Jerrett et al. (2009) analyzed the ACS CPS-II cohort, focusing on the relationship between long-term $\mathrm{O}_{3}$ exposure and the RR of deaths by respiratory causes. The analysis spanned data on daily maximum $\mathrm{O}_{3}$ concentrations between 1 April and 30 September for the years 1977 to 2000. In the two-pollutant model with a known constant concentration of $\mathrm{PM}_{2.5}$, an increase of $10 \mathrm{ppbv}$ of the seasonal (AprilSeptember) average daily one-hourly maximum $\mathrm{O}_{3}$ mixing 
ratio is associated with an increase of $4.0 \%$ (95\% CI: $1.3-$ $6.7 \%$ ) respiratory mortality, based on a mean $\mathrm{RR}=1.04$, and $\mathrm{CRF}=0.003922$.

We used concentrations of $\mathrm{PM}_{2.5}$ and $\mathrm{O}_{3}$ for the year 2005 and the preindustrial conditions obtained by Pozzer et al. (2012a) applying the EMAC atmospheric chemistry general circulation model (Jöckel et al., 2006; Pringle et al., 2010; de Meij et al., 2012; Astitha et al., 2012). We focus on 2005 because for this year a new, relatively high-resolution dataset of anthropogenic emissions is available (Doering et al., 2009; Pozzer et al., 2012b), and also because the meteorology of 2005 may be considered representative, i.e., without major annual modes (e.g., El Niño, North Atlantic Oscillation). The model has a horizontal resolution of about $1.1^{\circ} \times$ $1.1^{\circ}(\sim 100 \mathrm{~km}$ latitude and longitude near the Equator), and a vertical resolution of 31 levels up to the lower stratosphere, of which the surface concentrations were used for this study. The concentrations of $\mathrm{PM}_{2.5}$ used here are the yearly averages, and those of $\mathrm{O}_{3}$ the averages of the six-month daily maximum concentrations obtained with the model version of Pozzer et al. (2012a). The anthropogenic concentrations of $\mathrm{PM}_{2.5}$ and $\mathrm{O}_{3}$ were calculated as the differences between the year 2005 and the preindustrial conditions (i.e., the latter from a model simulation including only natural emissions).

Model evaluation based on in situ and remote sensing observations indicates that the simulations reproduce the main spatial atmospheric distribution of the sulfate and ammonium aerosols. For nitrate some differences were found. The analysis of black and organic carbon (BC and OC) over Europe shows that the model typically overestimates BC. Over the USA the aerosol components $\mathrm{BC}$ and $\mathrm{OC}$ are in general overestimated and over China underestimated by the model (de Meij et al., 2012; Pozzer et al., 2012b). Nevertheless, the seasonal distribution of aerosol optical depth (AOD) is well represented by the model and the results agree well with observed $\mathrm{PM}_{2.5}$ and $\mathrm{O}_{3}$, and particularly well with total oxidant, i.e., $\mathrm{O}_{x}=\mathrm{NO}_{2}+\mathrm{O}_{3}$ (Pozzer et al., 2012a). Comparison of model calculated AOD with ground-based and satellite remote sensing data indicates generally high spatial and temporal correlations, with negative biases in biomass burning and dust outflow regions over the oceans (de Meij et al., 2012; Pozzer et al., 2012b). Since we do not consider dust as part of the anthropogenic $\mathrm{PM}_{2.5}$ and population is sparse in the marine environment this is of limited consequence in the present study.

Global population numbers for 2005 were obtained from the Columbia University Center for International Earth Science Information Network (CIESIN) database with a resolution of $2.5 \times 2.5$ arc minutes $\left(\sim 0.04^{\circ} \times 0.04^{\circ}\right.$; CIESIN, 2005). Since our study is based on epidemiological research that focuses on the ACS CPS-II cohort, the global population over the age of 30 was used as the population variable (Pop) in the health impact function. The annual United Nations Population Division (UNPD) publication World Population Prospects reports the total annual population numbers of each country for $5 \mathrm{yr}$ age groups. The global population of $\geq 30 \mathrm{yr}$ in age was computed as the fraction of people of $\geq 30 \mathrm{yr}$ in each country from the UNDES (2011), and applying these fractions to the appropriate grid cells of CIESIN data to obtain the total and gridded global target population. The total global population of $30 \mathrm{yr}$ and older in 2005 is calculated to amount to 2.93 billion individuals.

The disability-adjusted life years (DALYs) of a population encompass the years of healthy life unfulfilled by individuals in the population due to both poor health and mortality. The DALYs are quantified as the sum of the years lost due to disability (YLD) and the years of life lost by premature mortality (YLL; WHO, 2008). In this study, we only examine the premature deaths due to air pollution, and thus focus on YLL as the measure of DALYs. YLL is given by the function

$\Delta \mathrm{YLL}=\Delta \operatorname{Mort}\left(\mathrm{YLL}_{0} / y_{0}\right)$,

where $\triangle Y L L$ is the YLL due to premature mortality caused by $\mathrm{PM}_{2.5}$ and $\mathrm{O}_{3}$ pollution; and $\mathrm{YLL}_{0}$ is the baseline YLL. Baseline YLL data were retrieved from the WHO Health Statistics and Health Information System for the year 2004 with $3 \%$ discounting and age weights, where younger ages are given a higher value than the later years in an individual's life (WHO, 2008).

In the next section, we present the calculated global levels of anthropogenic air pollution, premature mortality rates and the associated YLL by categorizing the model results according to WHO regions, sub-regions and mortality strata (WHO, 2002). The calculations have been performed at the resolution of the most detailed dataset (i.e., $0.04^{\circ}$ of the population data) and then aggregated to higher levels up to country, regional and global scales. The WHO divides the world into six regions, 14 epidemiological sub-regions, while five strata are applied to these regions to further classify the mortality risk of the populations within a given region (Table A1).

\section{Results}

The model calculated increases in $\mathrm{PM}_{2.5}$ concentrations $\left(\mu \mathrm{g} \mathrm{m}^{-3}\right)$ and $\mathrm{O}_{3}$ mixing ratios (ppbv) between preindustrial times (approximately mid-19th century) and 2005 are presented in Fig. 1. High levels of air pollution are typically found in the USA, Europe, the Middle East, South and East Asia. In the USA anthropogenic $\mathrm{PM}_{2.5}$ is highest in the east; $\mathrm{O}_{3}$ in the central-south and southwest. In Europe $\mathrm{PM}_{2.5}$ increases are highest in the central-west and $\mathrm{O}_{3}$ in the south. The highest anthropogenic $\mathrm{PM}_{2.5}$ levels worldwide are found in eastern China, while in most of East and South Asia PM $_{2.5}$ can be very high. In these extensive, economically emerging regions large populations are exposed to strongly growing levels of particulate air pollution.

In eastern India and southeastern China anthropogenic $\mathrm{O}_{3}$ is also rather high. It is also high in the Mediterranean and Middle East, and has a global maximum around the Arabian 

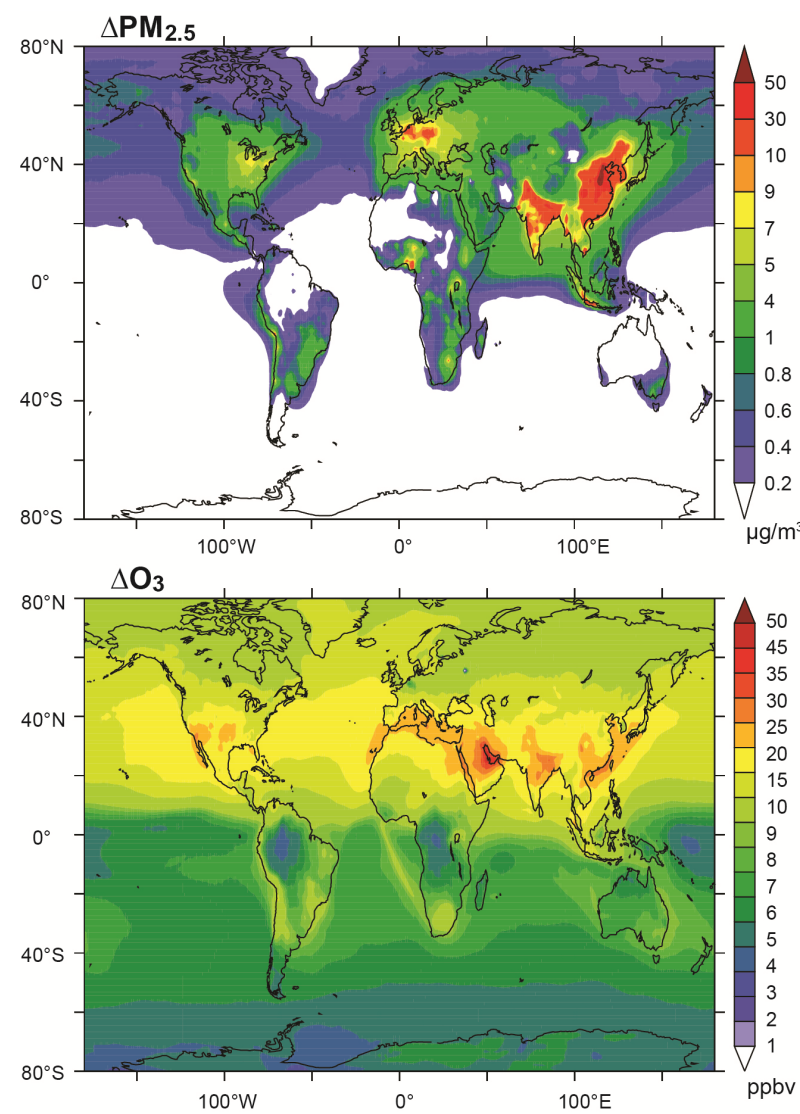

Fig. 1. Model calculated annual average increases of anthropogenic $\mathrm{PM}_{2.5}$ and $\mathrm{O}_{3}$ from the preindustrial era until 2005.

Gulf. It should be emphasized that some regions are additionally affected by natural $\mathrm{PM}_{2.5}$; mainly mineral dust particles in North Africa, the Middle East and East Asia. Though these are accounted for in our model, they are not part of the present analysis because mineral dust is assumed to be natural and its sources were the same in both the preindustrial and present-day simulations. For an overview of global air pollution and regional hot spots of poor air quality, see e.g., Sokhi (2011). Model calculated regional distributions and budgets of aerosol pollution are discussed in Pozzer et al. (2012b).

Our model results suggest that $69 \%$ of the population worldwide is exposed to an annual mean anthropogenic $\mathrm{PM}_{2.5}$ concentration higher than $10 \mu \mathrm{g} \mathrm{m}^{-3}$, being the air quality guideline of the WHO. Further, $33 \%$ of the population is exposed to a mean anthropogenic $\mathrm{PM}_{2.5}$ concentration of $>25 \mu \mathrm{g} \mathrm{m}^{-3}$ (EU Directive), and $20 \%$ to $>35 \mu \mathrm{g} \mathrm{m}^{-3}$ (WHO Level 1 Interim Target). Brauer et al. (2012) performed similar model calculations, indicating that $89 \%$ of the global population is exposed to an annual mean $\mathrm{PM}_{2.5}$ concentration of $>10 \mu \mathrm{g} \mathrm{m}^{-3}$ and $32 \%$ to $>35 \mu \mathrm{g} \mathrm{m}^{-3}$. Since Brauer et al. (2012) included all $\mathrm{PM}_{2.5}$ sources, thus including natural mineral dust, sea salt, etc., whereas we focus on anthropogenic $\mathrm{PM}_{2.5}$, it seems that these estimates are largely consistent and differences are well within the statistical uncertainty of the $\mathrm{PM}_{2.5}$ calculations (Sect. 4).

The epidemiological calculations, based on our model output, indicate that the exposure of the global population to anthropogenic $\mathrm{PM}_{2.5}$ causes a premature mortality of about 2.0 million by cardiovascular disease and 186 thousand by lung cancer in the year 2005 (Table 1). The global distribution is shown in the top panel in Fig. 2. This is equivalent to an annual mortality of 689 and 64 per million capita of $\geq 30 \mathrm{yr}$ in age, respectively. The WHO strata Wpr-B (Western Pacific) and Sear-D (Southeast Asia) are most strongly impacted by excess cardiovascular mortalities, about 955 and 519 thousand/year, respectively. Further analysis on the country level reveals that almost all premature deaths in the Wpr-B stratum occur in China (nearly 900 thousand/year), which ranks highest on the country list for cardiovascular mortality (Table 2). India is second with a total estimated premature mortality of about 421 thousand/year. Additional nations in South and East Asia with high rankings in Table 2 are Bangladesh and Pakistan, with premature cardiovascular mortality rates of 60-65 thousand/year. An estimated global total of about 14.3 million YLL is due to premature cardiovascular mortality (Table 1). About $75 \%$ is found to occur in the Wpr-B and Sear-D strata.

The the Wpr-B stratum in the Western Pacific also has a large share $(63 \%)$ in the global premature mortality by lung cancer of about 186 thousand/year. Southeast Asia and also the Eur-A stratum, mostly in western Europe, contribute significantly to the total mortality (both with $\sim 18$ thousand/year, i.e., both about $10 \%$ of the global premature mortality by lung cancer) (Table 1). The global distribution is shown in the middle panel in Fig. 2. The country level analysis reveals that, of the 117 thousand deaths/year estimated in the Wpr-B stratum, about 108 thousand occur in China (Table 2). When normalized to the number of inhabitants, the country rankings can change drastically, except for China. While China is present at or near the top according to all rankings, the subsequent two countries with the highest premature mortality rates by lung cancer (India and USA) are substituted by the smaller nations Belgium and the Netherlands (Table 2). Note that the top ranking of eastern European countries according to Table 2 is partly related to the high baseline mortality rates in the Eur-C stratum $\left(1.45 \% \mathrm{yr}^{-1}\right.$ for cardiovascular mortality, i.e., between 2 and 3 times the BMRs for other strata, see Table 1). The analysis of YLL due to premature lung cancer mortality reveals a worldwide total of around 1.7 million years of life lost/year (Table 1). Of this total, the majority (nearly $64 \%$ ) is again found in the Wpr-B stratum of the Western Pacific region.

Anthropogenic $\mathrm{O}_{3}$ is estimated to result in about 0.77 million/year respiratory deaths globally, equivalent to 264 per million capita/year ( $\geq 30 \mathrm{yr}$ in age) (Table 1). The global distribution is shown in the lower panel in Fig. 2. The largest share of all strata is again by Wpr-B in the Western Pacific region with $39 \%$, and the second largest by Sear-D, mostly 
Table 1. Baseline mortality rate, mortality (in thousands and per million capita), and YLL by cardiovascular and lung cancer deaths related to anthropogenic $\mathrm{PM}_{2.5}$ and respiratory mortality related to $\mathrm{O}_{3}$, for the population $\geq 30 \mathrm{yr}$, calculated for the WHO mortality strata in 2005 .

\begin{tabular}{|c|c|c|c|c|c|c|c|c|c|c|c|c|c|c|}
\hline & \multirow[b]{3}{*}{ Stratum } & \multirow[b]{3}{*}{$\begin{array}{r}\text { People } \\
\geq 30 \mathrm{yr} \\
\text { (millions) }\end{array}$} & \multicolumn{8}{|c|}{$\mathrm{PM}_{2.5}$} & \multirow{2}{*}{\multicolumn{4}{|c|}{$\begin{array}{c}\mathrm{O}_{3} \\
\text { Respiratory mortality }\end{array}$}} \\
\hline & & & \multicolumn{4}{|c|}{ Cardiovascular mortality } & \multicolumn{4}{|c|}{ Lung cancer } & & & & \\
\hline & & & $\begin{array}{l}\text { Baseline } \\
\text { mortality } \\
\left(\% \mathrm{yr}^{-1}\right)\end{array}$ & $\begin{array}{r}\text { Persons } \\
\text { (thousands) }\end{array}$ & $\begin{array}{r}\text { Per } 10^{6} \\
\text { capita } \\
\geq 30 \mathrm{yr}\end{array}$ & $\begin{array}{r}\text { YLL } \\
\text { (thousands) }\end{array}$ & $\begin{array}{l}\text { Baseline } \\
\text { mortality } \\
\left(\% \mathrm{yr}^{-1}\right)\end{array}$ & $\begin{array}{r}\text { Persons } \\
\text { (thousands) }\end{array}$ & $\begin{array}{r}\text { Per } 10^{6} \\
\text { capita } \\
\geq 30 \mathrm{yr}\end{array}$ & $\begin{array}{r}\text { YLL } \\
\text { (thousands) }\end{array}$ & $\begin{array}{l}\text { Baseline } \\
\text { mortality } \\
\left(\% \mathrm{yr}^{-1}\right)\end{array}$ & $\begin{array}{r}\text { Persons } \\
\text { (thousands) }\end{array}$ & $\begin{array}{r}\text { Per } 10^{6} \\
\text { capita } \\
\geq 30 \mathrm{yr}\end{array}$ & $\begin{array}{r}\text { YLL } \\
\text { (thousands) }\end{array}$ \\
\hline \multirow[t]{2}{*}{ Africa } & Afr-D & 99 & 0.54 & 23 & 232 & 207 & 0.01 & 0.5 & 5 & 5 & 0.31 & 26 & 256 & 274 \\
\hline & Afr-E & 109 & 0.51 & 17 & 156 & 155 & 0.01 & 0.4 & 4 & 5 & 0.27 & 14 & 129 & 151 \\
\hline \multirow[t]{3}{*}{ Americas } & Amr-A & 199 & 0.42 & 49 & 249 & 245 & 0.09 & 10 & 50 & 73 & 0.12 & 42 & 210 & 194 \\
\hline & Amr-B & 202 & 0.42 & 15 & 73 & 103 & 0.03 & 1 & 5 & 9 & 0.14 & 21 & 101 & 124 \\
\hline & Amr-D & 28 & 0.34 & 2 & 59 & 12 & 0.02 & 0.1 & 3 & 1 & 0.17 & 3 & 99 & 18 \\
\hline Southeast & Sear-B & 140 & 0.45 & 60 & 428 & 497 & 0.04 & 5 & 37 & 48 & 0.22 & 26 & 187 & 219 \\
\hline Asia & Sear-D & 524 & 0.58 & 519 & 990 & 4452 & 0.02 & 18 & 34 & 170 & 0.29 & 207 & 394 & 1781 \\
\hline \multirow[t]{3}{*}{ Europe } & Eur-A & 264 & 0.55 & 121 & 460 & 505 & 0.07 & 18 & 67 & 136 & 0.12 & 46 & 174 & 180 \\
\hline & Eur-B & 109 & 0.94 & 62 & 573 & 409 & 0.06 & 5 & 49 & 52 & 0.09 & 12 & 107 & 82 \\
\hline & Eur-C & 140 & 1.45 & 93 & 669 & 666 & 0.06 & 4 & 30 & 42 & 0.10 & 15 & 106 & 144 \\
\hline Eastern & Emr-B & 57 & 0.53 & 6 & 112 & 51 & 0.01 & 0.2 & 3 & 2 & 0.08 & 7 & 121 & 54 \\
\hline Mediterranean & Emr-D & 1267 & 0.67 & 71 & 563 & 610 & 0.02 & 2 & 17 & 23 & 0.17 & 25 & 198 & 234 \\
\hline Western & Wpr-A & 103 & 0.37 & 24 & 229 & 105 & 0.07 & 5 & 46 & 29 & 0.16 & 28 & 271 & 91 \\
\hline Pacific & Wpr-B & 829 & 0.45 & 955 & 1,152 & 6239 & 0.05 & 117 & 141 & 1,072 & 0.23 & 303 & 366 & 1664 \\
\hline World & & 2930 & 0.70 & 2019 & 689 & 14260 & 0.05 & 186 & 64 & 1665 & 0.16 & 773 & 264 & 5215 \\
\hline
\end{tabular}

Table 2. Top ten countries with the highest annual premature cardiovascular, lung cancer and respiratory mortality related to $\mathrm{PM}_{2.5}$ and $\mathrm{O}_{3}$ (total and per capita) for the population $\geq 30 \mathrm{yr}$ old in 2005 .

\begin{tabular}{|c|c|c|c|c|c|c|c|c|c|c|c|c|}
\hline & \multicolumn{8}{|c|}{$\mathrm{PM}_{2.5}$} & \multirow{2}{*}{\multicolumn{4}{|c|}{$\frac{\mathrm{O}_{3}}{\text { Respiratory mortality }}$}} \\
\hline & \multicolumn{4}{|c|}{ Cardiovascular mortality } & \multicolumn{4}{|c|}{ Lung cancer } & & & & \\
\hline & \multicolumn{2}{|c|}{ Total (thousands) } & \multicolumn{2}{|l|}{$\%$ per capita } & \multicolumn{2}{|c|}{ Total (thousands) } & \multicolumn{2}{|c|}{$\%$ per capita } & \multicolumn{2}{|c|}{ Total (thousands) } & \multicolumn{2}{|l|}{$\%$ per capita } \\
\hline 1 & China & 898 & China & 0.13 & China & 108 & China & 0.02 & China & 273 & Algeria & 0.04 \\
\hline 2 & India & 421 & Bangladesh & 0.12 & India & 14 & Belgium & 0.01 & India & 170 & Macao & 0.04 \\
\hline 3 & Bangladesh & 65 & Pakistan & 0.12 & USA & 9.1 & Netherlands & 0.01 & USA & 38 & Taiwan & 0.04 \\
\hline 4 & Pakistan & 60 & Czech Republic & 0.10 & Germany & 4.5 & Macao & 0.01 & Japan & 27 & Bangladesh & 0.04 \\
\hline 5 & Russia & 46 & Hungary & 0.10 & Japan & 4.5 & Hungary & 0.01 & Bangladesh & 23 & Hong Kong & 0.04 \\
\hline 6 & USA & 46 & Korea (Dem. Rep.) & 0.10 & Indonesia & 3.8 & Hong Kong & 0.01 & Indonesia & 16 & Korea (Dem. Rep.) & 0.04 \\
\hline 7 & Indonesia & 44 & Ukraine & 0.10 & Viet Nam & 3.6 & Czech Republic & 0.01 & Pakistan & 12 & India & 0.04 \\
\hline 8 & Germany & 39 & India & 0.10 & Korea & 2.8 & Poland & 0.01 & Nigeria & 11 & China & 0.04 \\
\hline 9 & Viet Nam & 30 & Macao & 0.10 & France & 2.6 & Viet Nam & 0.01 & Viet Nam & 10 & Nepal & 0.04 \\
\hline 10 & Ukraine & 29 & Bulgaria & 0.10 & U.K. & 2.5 & Korea & 0.01 & U.K. & 9.5 & Bhutan & 0.03 \\
\hline
\end{tabular}

in southern Asia with a contribution of $27 \%$. The country level analysis indicates that China (273 thousand premature deaths/year) and India (170 thousand/year) are the top two nations globally for respiratory mortality by $\mathrm{O}_{3}$ pollution (Table 2). When normalizing according to population numbers, Algeria, Macao and Taiwan rather lead the ranking with highest per capita respiratory mortality. Worldwide, a total of more than 5.2 million YLL is estimated due to respiratory disease (Table 1). The top three contributing strata to this YLL estimate are Sear-D (34\%), largely in South Asia, Wpr-B (32\%) in the Western Pacific region, and the Emr-D (the region between Morocco and Afghanistan) and Afr-D (mostly Central-West Africa) strata (5\%).

Figure 3 presents four regions with enhanced premature mortality by $\mathrm{PM}_{2.5}$ and $\mathrm{O}_{3}$ (sum of lung cancer, cardiovascular and respiratory disease). Urban and industrial areas with strong pollution emissions and high population density can be identified in Fig. 3, often in combination with meteorological conditions favorable for enhanced air pollution, e.g., low rainfall and sunny conditions (slow $\mathrm{PM}_{2.5}$ removal, strong photochemical $\mathrm{O}_{3}$ formation). In the USA several of the major cities, such as New York, Philadelphia, Baltimore and Washington, and also Chicago, Atlanta, Houston and Dallas can be recognized. In Europe the Ruhr area and Cologne (western Germany), Paris, the Randstad conurbation in the Netherlands, Belgium, major cities in the UK (London) and the Po Valley near Milan stand out. Southern Poland (Krakow), Hungary (Budapest), the western and eastern Ukraine (Donetsk) and Istanbul are also prominent with high premature mortality rates.

Figure 3 shows that the highest mortality rates worldwide are found in northern India, Bangladesh and eastern China. In India the populous Indo-Gangetic Plain (especially the central area) and megacities such as Delhi, Kolkata and Mumbai are locations of major premature mortality by air pollution. In China the regions from Beijing and Tianjin down to Xi' an, 


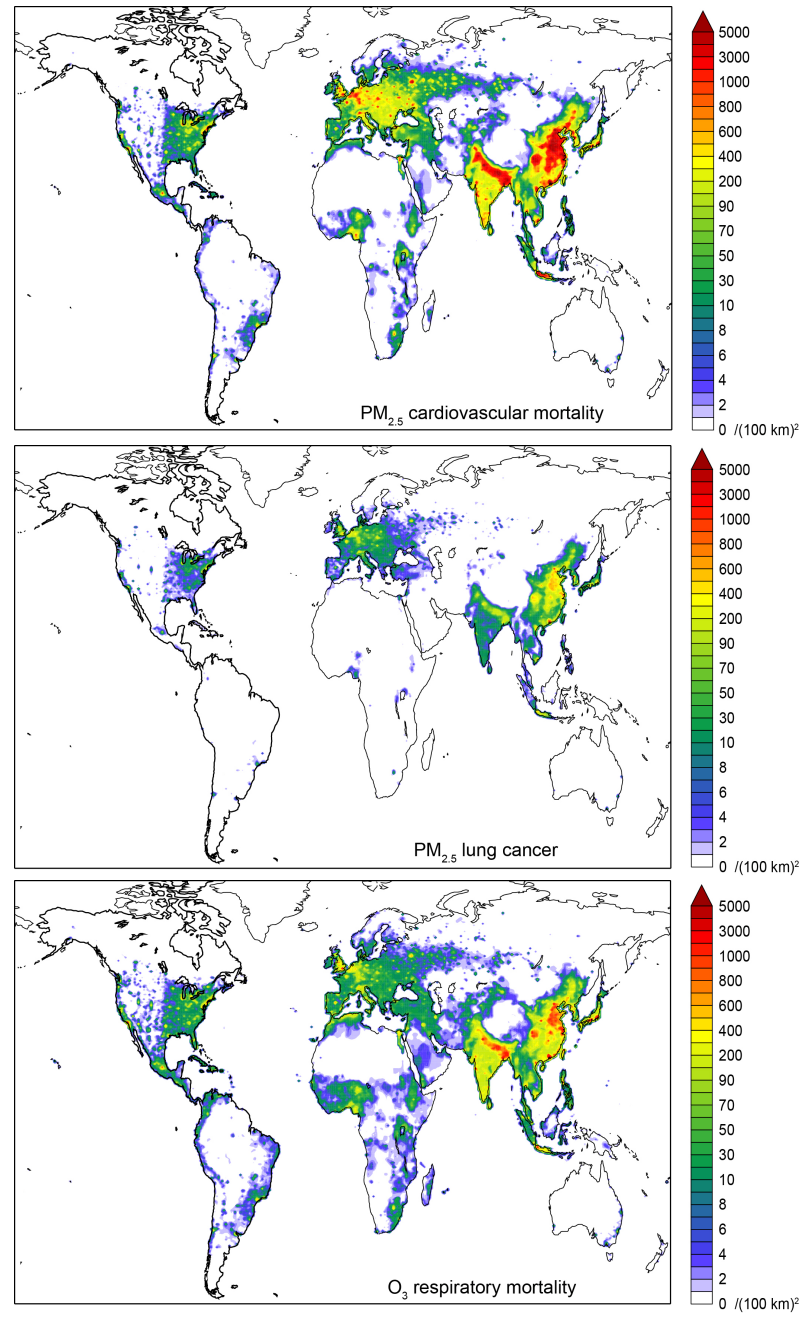

Fig. 2. Global premature mortality by cardiovascular, lung cancer and respiratory disease (individuals per $100 \mathrm{~km} \times 100 \mathrm{~km}$ ) due to $\mathrm{PM}_{2.5}$ and $\mathrm{O}_{3}$ for the population $\geq 30 \mathrm{yr}$ in 2005 .

Shanghai and Nanjing, the Pearl River area, Hong Kong, and Szechuan Province are strongly affected. Further east, major metropolitan areas in South Korea (Seoul) and Japan (Tokyo, Osaka) also have high rates of premature mortality.

In Table 3 we ranked the 20 megacities and major population centers in terms of globally highest mortality rates due to air pollution. These urban areas were selected through an algorithm that assigns a threshold population density greater than 2000 individuals per $\mathrm{km}^{2}$ and subsequently selects coherent areas with the largest populations. Several of the megacities in South and East Asia rank high on the list, including also Jakarta in Indonesia and Karachi in Pakistan. The number of YLL is highest in the Pearl River area (excluding Hong Kong) with $>276$ thousand/year out of a population of nearly 40 million. The cities that rank second and third are in India, i.e., Delhi and Kolkata (population nearly
19 million), for which we calculate a YLL of about 153 thousand and 124 thousand/year, respectively.

Alternatively, if we rank the megacities according to per capita premature mortality for individuals over 30 , the highest rates are calculated for Tianjin, Beijing and Delhi, followed by the Szechuan area, Shanghai and Kolkata. The per capita mortalities in these cities are estimated at 0.19$0.28 \% \mathrm{yr}^{-1}$. Again, it should be kept in mind that we only account for anthropogenically enhanced mortality rates by non-mineral aerosols. Thus, road dust, dust from construction sites, agricultural activities and desert dust are not accounted for in the present study. This can be relevant for several cities, e.g., in South and East Asia and especially in North Africa and the Middle East, so that our mortality rates by $\mathrm{PM}_{2.5}$ for these locations are expected to be conservative estimates.

\section{Discussion of uncertainties}

The use of the concentration response function of Jerrett et al. (2009) to estimate respiratory mortality attributable to long-term ozone exposure by Anenberg et al. (2010) was criticized by Prueitt and Goodman (2011). They suggested that the study should not be extrapolated globally and that no causal association has been established. In their reply Anenberg et al. (2011) justify the use of RR estimates from Jerrett et al. (2009) considering that they are consistent with the RR estimates used for long-term $\mathrm{PM}_{2.5}$ mortality (Krewski et al., 2009). They also argue that socioeconomic data are not strong confounders and that national data of the USA may be considered more representative than other available data, which are rather city specific. Anenberg et al. (2011) acknowledge, however, that by applying alternative RR estimates by Bell et al. (2004) the global premature respiratory deaths decreased by about $50 \%$. Fann et al. (2012) found this decrease to be even larger, i.e., $75 \%$. Since the RRs by Bell et al. (2004) only account for the short-term mortality by $\mathrm{O}_{3}$, whereas Jerrett et al. (2009) address the long-term impacts, it is expected that the latter are higher.

We reiterate that the concentration response functions applied here have been based on epidemiological cohort studies by the American Cancer Society (ACS), and do not necessarily characterize conditions in other countries for which such information is lacking. For example, the toxicity of particulates in different parts of the world is not necessarily the same. However, for regions with comparable sources of air pollution and a similar range of living conditions as in the USA the ACS results appear to be representative. For example, COMEAP (2009) concludes that the "ACS cohort study of several hundred thousand people in metropolitan areas across the USA forms the best source of coefficients suitable for application in the UK", in agreement with a combined European and North American study of air pollution and health (Samoli et al., 2008). Furthermore, factors such 

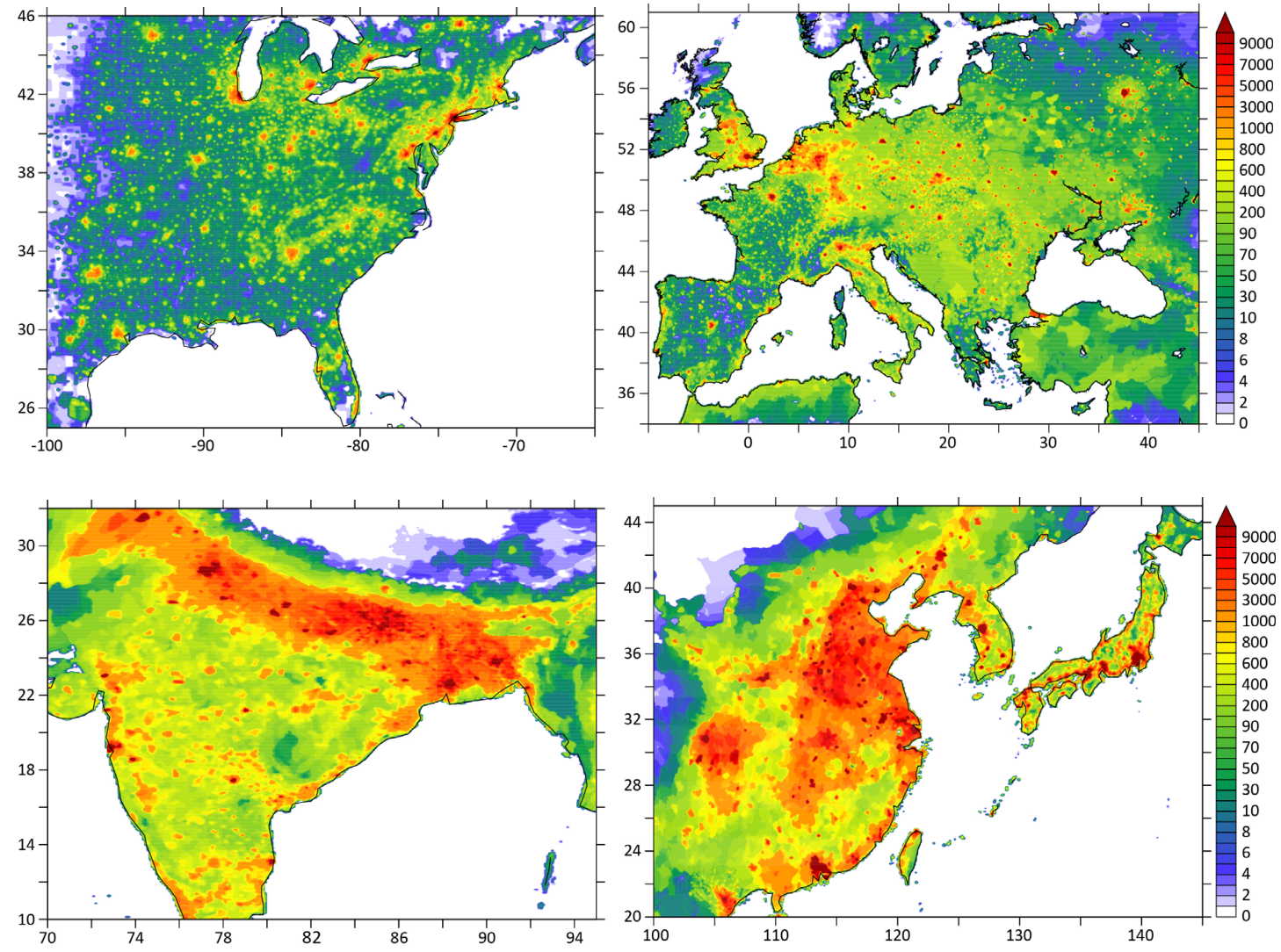

Fig. 3. Sum of cardiovascular, lung cancer and respiratory mortality related to $\mathrm{PM}_{2.5}$ and $\mathrm{O}_{3}$ in the eastern USA, Europe, southern and eastern Asia in 2005 (individuals per $100 \mathrm{~km} \times 100 \mathrm{~km}$ ). The level of detail in these figures represents a resolution of $\sim 10 \mathrm{~km}$ based on the population data $(\sim 4 \mathrm{~km})$ and atmospheric composition model output $(\sim 100 \mathrm{~km})$.

as smoking (including passive smoking), occupational hazards and personal characteristics are not expected to be confounding factors, since they do not vary with air pollution on a daily basis in epidemiological studies (Ostro, 2004) and are expected to be adequately accounted for in epidemiological studies (Roman et al., 2008). On the other hand, in countries where the chemical composition of particulates and the exposure conditions are rather different, e.g., in Southeast Asia and the western Pacific region (with high premature mortality rates), the ACS results are likely to be less representative, and region specific epidemiological studies are needed (Cohen et al., 2005).

For the comparison of RRs used here with others in the literature, we recall that Krewski et al. (2009) report cardiopulmonary disease (CPD) by $\mathrm{PM}_{2.5}$, whereas ideally one should distinguish cardiovascular (CVD) and respiratory disease by $\mathrm{PM}_{2.5}$. Lung cancer is reported separately. Also, because we use CVD data for the baseline mortality rates, we expect the discrepancy to be small. Amann and Schöpp (2011) present a compilation of RRs based on several recent cohort studies associated with a $10 \mu \mathrm{g} \mathrm{m}^{-3}$ change in $\mathrm{PM}_{2.5}$ in the USA and Europe, based on data by R.T. Burnett (linear relative risk model for adult mortality associated with $\mathrm{PM}_{2.5}$ exposure - Methodology for the 2005 Global Burden of Disease Outdoor Air Pollution project, 2010). The reported ranges of RRs are

$$
\begin{array}{ll}
\text { Cardiovascular disease } & \mathrm{RR}=1.11-1.76(0.93-2.47) ; \\
\text { Respiratory disease } & \mathrm{RR}=1.06-1.08(0.79-1.52) ; \\
\text { Lung cancer } & \mathrm{RR}=1.06-1.14(0.82-1.69) \text {. }
\end{array}
$$

The overall $95 \%$ confidence intervals from all studies are indicated in parentheses. Since CPD is dominated by CVD (for which we use $R R=1.129$ ), it follows that the RRs by the ACS used here are well within the range of estimates of epidemiological cohort studies, i.e., rather toward the lower end (except lung cancer for which we use $R=1.137$ ), and also that the RRs derived in different studies are quite consistent.

In addition to statistical uncertainty (addressed below) and non-representativeness of epidemiological studies in the USA for other regions (i.e., the choice of the CRF), the assumed shape of the CRF contributes to uncertainty, which has been addressed by Cohen et al. $(2004,2005)$ through sensitivity analyses. They considered three alternatives: (i) no 
Table 3. Megacities and major population centers with highest mortality due to air pollution worldwide. Ranking in absolute numbers (highest YLL), and in parentheses the relative ranking according to the per capita mortality for individuals older than $30 \mathrm{yr}$.

\begin{tabular}{|c|c|c|c|c|c|c|c|c|c|c|}
\hline & $\begin{array}{l}\text { Megacity, } \\
\text { population } \\
\text { center }\end{array}$ & $\begin{array}{r}\text { Population } \\
\text { (million) }\end{array}$ & $\begin{array}{r}\text { Population } \\
\geq 30 \mathrm{yr} \\
\text { (million) }\end{array}$ & $\begin{array}{r}\mathrm{PM}_{2.5} \\
\text { cardiovascular } \\
\text { mortality (per year) }\end{array}$ & $\begin{array}{r}\mathrm{PM}_{2.5} \text { Lung } \\
\text { cancer mortality } \\
\text { (per year) }\end{array}$ & $\begin{array}{r}\mathrm{O}_{3} \\
\text { Respiratory } \\
\text { mortality (per year) }\end{array}$ & $\begin{array}{r}\mathrm{PM}_{2.5}+\mathrm{O}_{3} \\
\text { mortality } \\
\text { (per year) }\end{array}$ & $\begin{array}{r}\text { YLL by } \mathrm{PM}_{2.5}+\mathrm{O}_{3} \\
\text { (per year) }\end{array}$ & $\begin{array}{r}\text { Sum mortality } \\
\text { per capita } \\
\left(\% \mathrm{yr}^{-1}\right)\end{array}$ & $\begin{array}{r}\text { Sum mortality per } \\
\text { capita } \geq 30 \mathrm{yr} \\
\left(\% \mathrm{yr}^{-1}\right)\end{array}$ \\
\hline 1 & Pearl River area (7) & 39.6 & 21.8 & 29182 & 3530 & 9713 & 42425 & 376253 & 0.11 & 0.19 \\
\hline 2 & Delhi (3) & 18.5 & 7.3 & 14121 & 485 & 3188 & 17794 & 153136 & 0.10 & 0.24 \\
\hline 3 & Kolkata (6) & 18.6 & 7.4 & 10503 & 362 & 3499 & 143657 & 123637 & 0.08 & 0.19 \\
\hline 4 & Jakarta (9) & 20.7 & 8.6 & 10316 & 882 & 2463 & 13662 & 114637 & 0.07 & 0.16 \\
\hline 5 & Shanghai (5) & 13.3 & 7.0 & 9975 & 1206 & 3338 & 14520 & 94528 & 0.11 & 0.20 \\
\hline 6 & Dhaka (8) & 17.4 & 6.2 & 7953 & 274 & 2689 & 10917 & 93966 & 0.06 & 0.17 \\
\hline 7 & Beijing (2) & 9.7 & 5.2 & 10204 & 1228 & 2395 & 13828 & 91048 & 0.14 & 0.26 \\
\hline 8 & Mumbai (10) & 16.7 & 6.6 & 6740 & 232 & 2694 & 9667 & 83211 & 0.06 & 0.15 \\
\hline 9 & Moscow (12) & 13.6 & 8.2 & 6930 & 299 & 822 & 8051 & 60347 & 0.06 & 0.10 \\
\hline 10 & Tokyo (24) & 28.5 & 19.5 & 5690 & 1135 & 6848 & 13674 & 54476 & 0.05 & 0.07 \\
\hline 11 & Seoul (25) & 19.2 & 11.3 & 4994 & 1289 & 1019 & 7303 & 50028 & 0.04 & 0.06 \\
\hline 12 & Szechuan area (4) & 5.1 & 2.8 & 4758 & 574 & 1269 & 6602 & 43307 & 0.13 & 0.24 \\
\hline 13 & Tianjin (1) & 3.9 & 2.1 & 4262 & 512 & 1036 & 5813 & 38237 & 0.15 & 0.28 \\
\hline 14 & Hong Kong (11) & 6.3 & 4.0 & 3727 & 452 & 1726 & 5906 & 37970 & 0.09 & 0.15 \\
\hline 15 & New York (20) & 12.2 & 7.1 & 3141 & 616 & 1807 & 5565 & 28536 & 0.05 & 0.08 \\
\hline 16 & Karachi (13) & 10.4 & 3.4 & 2385 & 76 & 776 & 3238 & 28517 & 0.03 & 0.09 \\
\hline 17 & Bangkok (19) & 7.5 & 4.0 & 1961 & 168 & 1045 & 3175 & 26590 & 0.04 & 0.08 \\
\hline 18 & Los Angeles (18) & 10.6 & 6.2 & 2171 & 426 & 2520 & 5118 & 25650 & 0.05 & 0.08 \\
\hline 19 & Istanbul (14) & 9.5 & 4.1 & 2977 & 215 & 558 & 3751 & 25531 & 0.04 & 0.09 \\
\hline 20 & Mexico City (28) & 18.0 & 7.5 & 2021 & 134 & 1516 & 3673 & 24531 & 0.02 & 0.05 \\
\hline
\end{tabular}

increase in excess mortality above $30 \mu \mathrm{g} \mathrm{m}^{-3} \mathrm{PM}_{2.5}$; (ii) linear increase of excess mortality above $30 \mu \mathrm{g} \mathrm{m}^{-3} \mathrm{PM}_{2.5}$; and (iii) increase with the log of the $\mathrm{PM}_{2.5}$ concentration across the entire range. The $30 \mu \mathrm{g} \mathrm{m}^{-3}$ level represents the annual average $\mathrm{PM}_{2.5}$ concentration that is typically not exceeded in most cities in Europe and North America, while in developing countries concentrations in cities are frequently much higher (Cohen et al., 2004). It is also the level up to which linearity of the CRF has been confirmed (Krewski et al., 2003). It was found that in case (i) excess mortality estimates decrease by $27-29 \%$, largely in developing countries, while in case (ii) mortality increases in the WPR-B, EMR-D, SEAR$B$ and SEAR-D strata. In case (iii) the RR increases more steeply below $30 \mu \mathrm{g} \mathrm{m}^{-3} \mathrm{PM}_{2.5}$. As a consequence, mean excess mortality is calculated to be about $63 \%$ higher in strata with relatively low $\mathrm{PM}_{2.5}$ concentrations (AMR-A, EUR-A, EUR-C, WPR-A) while the mortality in strata with high concentrations is relatively insensitive to the assumption of a loglinear CRF (Cohen et al., 2004). These results are consistent with those of Anenberg et al. (2012), indicating that the results are not strongly dependent on assumptions for the CRF. The relatively largest uncertainty in estimated effects on mortality is expected at lower $\mathbf{P M}_{2.5}$ concentrations (Roman et al., 2008) for which our method thus represents a conservative approach.

We carried out a statistical uncertainty analysis assuming random errors, by propagating the quantified errors of all terms in Eq. (1), estimated from the $95 \%$ confidence intervals (CI95), based on the following assumptions. From the CI95 for CPD reported by Krewski et al. (2009) we estimate an uncertainty range of $\pm 27 \%$ (applied to CVD), and for lung cancer (LC) of $\pm 100 \%$. From the CI95 for respiratory disease (RD) reported by Jerrett et al. (2009) we estimate an uncertainty range of $\pm 67 \%$. These uncertainties are multi- plied with the $2 \sigma$ standard deviations of the concentration response function $(\beta)$, being $0.0061,0.0064$ and 0.0019 for CVD, LC and RD, respectively.

For the population data we apply an uncertainty range of $\pm 2 \%$, considering that the UN Department of Economic and Social Affairs Population Division estimates the population data of a country like China uncertain by approximately this fraction (http://esa.un.org/unpd/wpp/). The uncertainties in the concentration changes of pollutants $(\Delta X)$ are represented by the model simulated annual $2 \sigma$ standard deviations for each location (i.e., all model grid cells at the surface). For the baseline mortalities $\left(y_{0}\right)$ we also apply the $2 \sigma$ standard deviations, area weighted over all relevant locations (populated grid cells). The error propagation calculations account for the covariance between the different terms in Eq. (1).

The results are listed in Table 4, indicating that the uncertainty ranges are typically a factor of two or more for relatively small strata. In the larger strata the uncertainties are smaller, about $\pm 5-50 \%$ for lung cancer and cardiovascular mortality and up to $\pm 10 \%$ for respiratory mortality. The global averages appear to be rather robust with a statistical uncertainty range up to about $\pm 5 \%$. The relatively small uncertainty ranges apply to the highest level of aggregation (large strata and global mean), while at the country and megacity level the uncertainties are much larger, typically exceeding a factor of two. Note that this analysis does not account for non-representativeness of the concentration response functions used, e.g., applying them to developing countries, which causes additional uncertainty. Further, we have assumed that the effects only apply to the part of the population of $30 \mathrm{yr}$ and older, so that these estimates represent lower limits. Yet, the influence of this assumption is expected to be small because the baseline mortality rates at ages under $30 \mathrm{yr}$ are low (COMEAP, 2010). Fann et al. (2012) 
estimated infant $(<1 \mathrm{yr})$ mortality due to $\mathrm{PM}_{2.5}$ to be less than a few percent compared to that for the age category $\geq 30 \mathrm{yr}$ in age.

\section{Comparison to previous work}

Ostro (2004) estimated premature mortality worldwide by particulate matter in the urban environment based on $\mathrm{PM}_{10}$ concentrations from monitoring stations and model-based estimates $\left(\mathrm{PM}_{10}\right.$ is $\mathrm{PM}$ with an aerodynamic diameter smaller than $10 \mu \mathrm{m}$ ). This implicitly includes road dust, dust from construction sites and natural sources, not accounted for in the present work. The $\mathrm{PM}_{2.5}$ levels used by Ostro (2004) were extrapolated from $\mathrm{PM}_{10}$ through scaling factors (see also Cohen et al., 2004). The applied RR for CPD is 1.155, being higher than ours, and 1.232 for lung cancer, being much higher than ours and outside the range of recent studies (Sect. 4). Yet the global premature mortality by CPD was estimated at 1.07 million/year, about half of our estimate. Since the difference cannot be attributed to the concentration response functions, it is probably due to the applied $\mathrm{PM}_{2.5}$ concentrations for which unfortunately no detailed documentation was presented (Ostro, 2004). At least part of the discrepancy is related to the fact that Ostro (2004) focused on the urban population.

Prüss-Üstün et al. (2008) composed country profiles of the environmental burden and disease for 192 of the WHO member states for the year 2002. They included the burden by outdoor air pollution through mean metropolitan $\mathrm{PM}_{10}$ measurements based on publicly available statistics. Hence this study also focused on the urban population. It included respiratory mortality among children under $5 \mathrm{yr}$ of age and cardiopulmonary and lung cancer mortality among adults older than $30 \mathrm{yr}$. Since the CRF of respiratory mortality is much lower than that of CPD and lung cancer mortality together, we assume that the results by Prüss-Üstün et al. are dominated by the two latter categories. By comparing our country-level estimates for CVD and lung cancer mortality, we find that for small countries, dominated by urban populations, our results and the Prüss-Üstün et al. study agree closely. On the other hand, for large countries with a wide range of population and pollution conditions, including a large rural populace, our estimates tend to be higher by an order of magnitude. This underscores the importance of including regions that are datasparse, often not included in public statistics, and the need to account for both rural and urban environments.

Ezzati et al. (2002) and Cohen et al. (2004, 2005) investigated cardiovascular and lung cancer mortality for adults of $\geq 30 \mathrm{yr}$ and acute respiratory infection mortality of children under $5 \mathrm{yr}$ of age for the year 2000. The estimated mortality was classified according to the 14 WHO sub-regions also used here. Both studies focused on the urban population and air pollution by $\mathrm{PM}_{2.5}$, reporting nearly 800 thousand excess deaths in the year 2000. The difference with our work is largely explained by the strongly growing urban population between 2000 and 2005, and the fact that we also account for the non-urban environment. Furthermore, Ezzati et al. (2002) and Cohen et al. (2004, 2005) assume a $\mathrm{PM}_{2.5}$ threshold of $7.5 \mu \mathrm{g} \mathrm{m}^{-3}$ below which human health is not affected (also assumed by Ostro, 2004). We did not adopt such a threshold because our calculations for the preindustrial atmosphere include natural aerosol concentrations, which are not much lower than $7.5 \mu \mathrm{g} \mathrm{m}^{-3}$. Another difference is that $\mathrm{PM}_{2.5}$ concentrations were estimated based on $\mathrm{PM}_{10}$ and total suspended particulate (TSP) measurements (fixed ratio $\mathrm{PM}_{2.5}: \mathrm{PM}_{10}$ : TSP of $0.5: 1: 2$; see Cohen et al., 2004), whereas we directly compute $\mathrm{PM}_{2.5}$.

A comparison with the global results of Anenberg et al. (2010), who applied the same methodology as we did but for the year 2000, indicates some significant differences (up to $50 \%$ ); especially our YLL calculations appear to be systematically lower. Our estimate of global respiratory mortalities (773 thousand/year) is about $10 \%$ higher (our YLL of 5.2 million/year is $\sim 15 \%$ lower). One difference is that we applied updated baseline mortality rates on the country level (when available), whereas Anenberg et al. (2010) integrated over six large regions. Our estimated mortality by cardiovascular disease ( 2 million/year) is about $40 \%$ lower than that by CPD reported by Anenberg et al. (2010) while our estimate for lung cancer (186 million/year) is about $15 \%$ lower. The combined years of life lost by $\mathrm{PM}_{2.5}(\sim 16$ million/year $)$ is nearly $50 \%$ lower than reported by Anenberg et al. (2010). Part of the disagreement may be due to the fact that CPD calculations by Anenberg et al. (2010) include a contribution by respiratory disease whereas we focus on CVD. Further, the use of a low-concentration threshold of $5.8 \mathrm{\mu g} \mathrm{m}^{-3}$ by Anenberg et al. (2010) may also explain part of the difference. We do not apply such a threshold, which could be relevant for regions affected by high concentrations of natural aerosols such as desert dust. Discrepancies may also be related to the finer grid resolution of our model, so that urban population and air pollution data are represented more consistently. A recent sensitivity study by Punger and West (2013) illustrates that reduced model resolution leads to a significant positive bias in the calculations of mortality due to $\mathrm{PM}_{2.5}$ (less for $\mathrm{O}_{3}$ ), especially at grid scales $>100 \mathrm{~km}$.

Fang et al. (2013) applied a global model at about $200 \mathrm{~km}$ grid resolution for the year 2000, applying the same CRFs as we did. They estimate a $\mathrm{PM}_{2.5}$ related mortality due to CPD of about 1.5 million/year (cf. our 2 million/year for CVD in 2005) and 95 thousand/year due to lung cancer (cf. our 186 thousand/year). For mortality by respiratory disease related to $\mathrm{O}_{3}$ they estimate 375 thousand/year (cf. our 773 thousand/year). Some of the discrepancy is explained by the different emission data for the years 2000 and 2005. In their comparison to the results of Anenberg et al. (2010) Fang et al. (2013) find that results are most sensitive to the assumed baseline concentrations or preindustrial emission scenario, 
Table 4. Mortality (in thousands) and the range (in percent) according to the $95 \%$ confidence interval (CI95) by cardiovascular and lung cancer deaths related to anthropogenic $\mathrm{PM}_{2.5}$ and respiratory mortality related to $\mathrm{O}_{3}$, for the population $\geq 30 \mathrm{yr}$, calculated for the WHO mortality strata in 2005. The ranges have been computed at the highest grid resolution available and were subsequently propagated and aggregated to the level of strata, including the covariance between the terms of Eq. (1), which leads to a decrease of the CI95 range at increasing levels of aggregation.

\begin{tabular}{|c|c|c|c|c|c|c|c|}
\hline & \multirow[b]{3}{*}{ Stratum } & \multicolumn{4}{|c|}{$\mathrm{PM}_{2.5}$} & \multicolumn{2}{|c|}{$\mathrm{O}_{3}$} \\
\hline & & \multicolumn{2}{|c|}{ Cardiovascular mortality } & \multicolumn{2}{|c|}{ Lung cancer } & \multicolumn{2}{|c|}{ Respiratory mortality } \\
\hline & & $\begin{array}{r}\text { Persons } \\
\text { (thousands) }\end{array}$ & $\begin{array}{r}\text { CI95 } \\
( \pm \%)\end{array}$ & $\begin{array}{r}\text { Persons } \\
\text { (thousands) }\end{array}$ & $\begin{array}{r}\mathrm{CI} 95 \\
( \pm \%)\end{array}$ & $\begin{array}{r}\text { Persons } \\
\text { (thousands) }\end{array}$ & $\begin{array}{r}\text { CI95 } \\
( \pm \%)\end{array}$ \\
\hline \multirow[t]{2}{*}{ Africa } & Afr-D & 23 & 109 & 0.5 & 118 & 25 & 4 \\
\hline & Afr-E & 17 & 30 & 0.4 & 54 & 14 & 6 \\
\hline \multirow[t]{3}{*}{ Americas } & Amr-A & 50 & 16 & 10 & 9 & 42 & 6 \\
\hline & Amr-B & 15 & 39 & 1 & 41 & 20 & 9 \\
\hline & Amr-D & 2 & 124 & 0.1 & 169 & 3 & 21 \\
\hline \multirow[t]{2}{*}{ Southeast Asia } & Sear-B & 60 & 19 & 5 & 16 & 26 & 8 \\
\hline & Sear-D & 519 & 5 & 18 & 9 & 207 & 2 \\
\hline \multirow[t]{3}{*}{ Europe } & Eur-A & 121 & 11 & 18 & 9 & 46 & 5 \\
\hline & Eur-B & 63 & 16 & 5 & 12 & 12 & 8 \\
\hline & Eur-C & 93 & 18 & 4 & 19 & 15 & 12 \\
\hline \multirow[t]{2}{*}{ Eastern Mediterranean } & Emr-B & 6 & 149 & 0.2 & 170 & 7 & 13 \\
\hline & Emr-D & 71 & 129 & 2 & 67 & 25 & 8 \\
\hline \multirow[t]{2}{*}{ Western Pacific } & Wpr-A & 24 & 45 & 5 & 28 & 28 & 11 \\
\hline & Wpr-B & 955 & 4 & 116 & 3 & 303 & 2 \\
\hline World & & 2019 & 5 & 186 & 3 & 773 & 1 \\
\hline
\end{tabular}

being rather uncertain due to the lack of historical measurement data needed to evaluate model results.

The most recent Global Burden of Disease (GBD) study (Lim et al., 2012) indicates 3.2 million deaths due to particulate matter pollution in the year 2010 (cf. our 2.2 million in 2005) and about 150 thousand due to $\mathrm{O}_{3}$ (cf. our 0.8 million in 2005). The relatively low number for ozone by GBD seems inconsistent with the results of earlier work that applied the concentration response factor (CRF) of Jerrett et al. (2009). Possibly another CRF was used, e.g., of Bell et al. (2004), yielding much lower mortality by $\mathrm{O}_{3}$, mostly because only short-term health effects are accounted for, whereas Jerrett et al. (2009) also include long-term effects. Unfortunately, the use of epidemiological parameters such as CRFs has not been documented by Lim et al. (2012), which impedes the comparison. It is also conceivable that different baseline concentrations were applied, based on model simulations with preindustrial emissions. The difference between GBD and our study for $\mathrm{PM}_{2.5}$ is largely explained by the fact that we focus on anthropogenic air pollution and do not include natural $\mathrm{PM}_{2.5}$ whereas the GBD study does.

On a country scale our model results can be compared with the work of Fann et al. (2012), who applied a regional model to the USA at $12 \mathrm{~km}$ resolution for the year 2005 . They applied different data sets for population and base- line mortalities, and the same CRFs as we did. Their estimated total $\mathrm{PM}_{2.5}$ related mortality is $130000 /$ year (cf. our estimate of 55000/year, and 141000/year of Anenberg et al. (2010) for N. America). For $\mathrm{O}_{3}$ they estimate 19000/year (cf. our estimate of 38 000/year, and $35000 /$ year of Anenberg et al. (2010) for N. America). Again, a main reason for differences appears to be the representation of background air pollution conditions. Fann et al. (2012) adopted fixed background concentrations for the eastern and western USA, e.g., 22 and 30 ppbv $\mathrm{O}_{3}$, respectively, probably higher than preindustrial conditions, although this is difficult to verify due to the absence of reliable data (see, e.g., Lelieveld and Dentener, 2000).

\section{Conclusions}

Our model results corroborate that in most areas premature mortality rates by anthropogenic air pollution are dominated by the adverse impacts of $\mathrm{PM}_{2.5}$, primarily by cardiovascular disease, while in some regions, e.g., in northeastern and Central America and rural areas in South and East Asia, respiratory disease by $\mathrm{O}_{3}$ can be of similar magnitude. We estimate that $69 \%$ of the global population is exposed to an annual mean anthropogenic $\mathrm{PM}_{2.5}$ concentration $>10 \mu \mathrm{g} \mathrm{m}^{-3}$ 
(WHO air quality guideline), $33 \%$ to $>25 \mu \mathrm{g} \mathrm{m}^{-3}$ (EU Directive) and $20 \%$ to $>35 \mu \mathrm{g} \mathrm{m}^{-3}$ (WHO Level 1 Interim Target). Note that these percentages do not account for natural background particulates such as mineral dust, which will be addressed in future work. In this work the use of Eq. (1) will need to be re-evaluated considering that CRFs for desert dust might be different from anthropogenic $\mathrm{PM}_{2.5}$. The present results suggest that anthropogenic $\mathrm{PM}_{2.5}$ and $\mathrm{O}_{3}$ cause the highest mortality in densely populated parts of Asia, with China and India contributing foremost on the country level.

The premature mortality rates by $\mathrm{PM}_{2.5}$ are highest in urban regions such as the Pearl River area, Delhi, Kolkata, Jakarta, Shanghai, Dhaka, Beijing, Mumbai, the Szechuan area, Tokyo, Seoul and others in South and East Asia. In addition, relatively high mortality rates are found in some $\mathrm{Eu}-$ ropean cities such as London, Paris, Berlin, Moscow, the Po Valley in northern Italy, the central part of the Netherlands, Belgium and the Ruhr area in Germany, and cities in North America such as Chicago, New York and Los Angeles. By considering per capita mortality, however, a somewhat different picture emerges, with urban and industrial areas in several eastern European countries ranking high (e.g., in Hungary, the Ukraine and Bulgaria). The highest premature respiratory mortality related to $\mathrm{O}_{3}$ is found in China, India, the USA, Japan and Bangladesh, whereas the per capita mortality is topmost in Algeria, Macao and Taiwan.

Our model results for the year 2005 indicate that globally the premature mortality rate due to $\mathrm{PM}_{2.5}$ is about 2.2 million/year $(\sim 0.08 \%$ per capita/year $)$ and by $\mathrm{O}_{3}$ nearly 0.8 million/year $(\sim 0.03 \%$ per capita/year), equivalent to approximately 16 and 5 million years of life lost per annum, respectively. The regions with the highest mortality due to air pollution worldwide are the Western Pacific $(\sim 46 \%)$, Southeast Asia $(\sim 25 \%)$ and Europe $(\sim 13 \%)$. Statistical uncertainty analysis shows that these global estimates are rather robust. At the level of small countries and urban centers, the uncertainties are much larger, typically higher than a factor of two. Comparison with other model-based studies suggests broad agreement for $\mathrm{PM}_{2.5}$ within a factor of two and poorer agreement for $\mathrm{O}_{3}$ with differences up to a factor of five. For total and $\mathrm{PM}_{2.5}$ related mortality our study seems conservative whereas for $\mathrm{O}_{3}$ related respiratory mortality other studies tend to be more conservative. One reason for discrepancies is the use of different emission data sets, in particular for the baseline, non-polluted (preindustrial) conditions or the use of low-concentration thresholds. In addition, different concentration response factors for $\mathrm{O}_{3}$ can cause substantial inconsistencies between studies. Furthermore, applying epidemiological factors from studies in the USA and Europe to other parts of the world contributes to uncertainty, for which region specific epidemiological studies are recommended.

\section{Appendix A}

$\begin{array}{ll}\text { Abbreviations and acronyms } \\ \text { ACS } & \text { American Cancer Society } \\ \text { AOD } & \text { Aerosol optical depth } \\ \text { BMR } & \text { Baseline mortality rate } \\ \text { CI } & \text { Confidence interval } \\ \text { CIESIN } & \begin{array}{l}\text { Columbia University Center for Interna- } \\ \text { tional Earth Science Information Network }\end{array} \\ \text { CRF } & \text { Concentration response function } \\ \text { CPD } & \text { Cardiopulmonary disease } \\ \text { CVD } & \text { Cardiovascular disease } \\ \text { DALY } & \text { Disability-adjusted life years } \\ \text { ECHAM } & \text { European Centre Model Hamburg } \\ \text { EMAC } & \text { ECHAM/MESSy Atmospheric Chemistry } \\ \text { MESSy } & \text { Modular Earth Submodel System } \\ \text { LC } & \text { Lung cancer } \\ \text { Mort } & \text { Annual mortality } \\ \text { PM } 2.5 & \text { Particulate Matter with an aerodynamic di- } \\ & \text { ameter smaller than } 2.5 \mu \text { m } \\ \text { PM } 10 & \text { PM with an aerodynamic diameter smaller } \\ & \text { than } 10 \mu \text { m } \\ \text { Pop } & \text { Total population with an age of } \geq 30 \text { yr } \\ \text { RD } & \text { Respiratory disease } \\ \text { RR } & \text { Relative risk } \\ \text { TSP } & \text { Total suspended particulates } \\ \text { UNDES } & \text { United Nations Department of Economic } \\ & \text { and Social Affairs } \\ \text { UNPD } & \text { United Nations Population Division } \\ \text { WHO } & \text { World Health Organization } \\ \text { YLD } & \text { Years lost due to disability } \\ \text { YLL } & \text { Years of life lost } \\ & \end{array}$


Table A1. WHO regions, mortality strata, child and adult mortality characteristics, and the countries and territories included.

\begin{tabular}{|c|c|c|c|c|}
\hline Region & Stratum & $\begin{array}{l}\text { Child } \\
\text { mortal- } \\
\text { ity }\end{array}$ & $\begin{array}{l}\text { Adult } \\
\text { mortal- } \\
\text { ity }\end{array}$ & Countries and territories within stratum \\
\hline \multirow[t]{2}{*}{ Africa } & Afr-D & High & High & $\begin{array}{l}\text { Algeria, Angola, Benin, Burkina Faso, Cameroon, Cape Verde, Chad, Comoros, } \\
\text { Equatorial Guinea, Gabon, Gambia, Ghana, Guinea, Guinea-Bissau, Liberia, } \\
\text { Madagascar, Mali, Mauritania, Mauritius, Mayotte, Niger, Nigeria, Reunion, } \\
\text { Saint Helena, Sao Tome and Principe, Senegal, Seychelles, Sierra Leone, Togo }\end{array}$ \\
\hline & Afr-E & High & $\begin{array}{l}\text { Very } \\
\text { high }\end{array}$ & $\begin{array}{l}\text { Botswana, Burundi, Central African Republic, Congo, Côte d'Ivoire, Demo- } \\
\text { cratic Republic of the Congo, Eritrea, Ethiopia, Kenya, Lesotho, Malawi, } \\
\text { Mozambique, Namibia, Rwanda, South Africa, Swaziland, Uganda, United Re- } \\
\text { public of Tanzania, Zambia, Zimbabwe }\end{array}$ \\
\hline \multirow[t]{3}{*}{ Americas } & Amr-A & $\begin{array}{l}\text { Very } \\
\text { low }\end{array}$ & $\begin{array}{l}\text { Very } \\
\text { low }\end{array}$ & Canada, Cuba, Greenland, Saint Pierre and Miquelon, United States of America \\
\hline & Amr-B & Low & Low & $\begin{array}{l}\text { Anguilla, Antigua and Barbuda, Argentina, Aruba, Bahamas, Barbados, Be- } \\
\text { lize, Bermuda, Brazil, British Virgin Islands, Cayman Islands, Chile, Colom- } \\
\text { bia, Costa Rica, Dominica, Dominican Republic, El Salvador, Falkland Is- } \\
\text { lands, French Guiana, Grenada, Guadeloupe, Guyana, Honduras, Jamaica, Mar- } \\
\text { tinique, Mexico, Montserrat, Netherland Antilles, Panama, Paraguay, Puerto } \\
\text { Rico, Saint Kitts and Nevis, Saint Lucia, Saint Vincent and the Grenadines, } \\
\text { Suriname, Trinidad and Tobago, Turks and Caicos Islands, United States Virgin } \\
\text { Islands, Uruguay, Bolivarian Republic of Venezuela }\end{array}$ \\
\hline & Amr-D & High & High & Bolivia, Ecuador, Guatemala, Haiti, Nicaragua, Peru \\
\hline \multirow[t]{2}{*}{ Southeast Asia } & Sear-B & Low & Low & Indonesia, Sri Lanka, Thailand \\
\hline & Sear-D & High & High & $\begin{array}{l}\text { Bangladesh, Bhutan, Democratic People's Republic of Korea, East Timor, In- } \\
\text { dia, Maldives, Myanmar, Nepal }\end{array}$ \\
\hline \multirow[t]{3}{*}{ Europe } & Eur-A & $\begin{array}{l}\text { Very } \\
\text { low }\end{array}$ & $\begin{array}{l}\text { Very } \\
\text { low }\end{array}$ & $\begin{array}{l}\text { Andorra, Austria, Belgium, Croatia, Cyprus, Czech Republic, Denmark, Faroe } \\
\text { Islands, Finland, France, Germany, Gibraltar, Greece, Guernsey, Iceland, Ire- } \\
\text { land, Isle of Man, Israel, Italy, Jersey, Liechtenstein, Luxembourg, Malta, } \\
\text { Monaco, Netherlands, Norway, Portugal, San Marino, Slovenia, Spain, Sval- } \\
\text { bard, Sweden, Switzerland, United Kingdom }\end{array}$ \\
\hline & Eur-B & Low & Low & $\begin{array}{l}\text { Albania, Armenia, Azerbaijan, Bosnia and Herzegovina, Bulgaria, Georgia, } \\
\text { Kyrgyzstan, Poland, Romania, Serbia and Montenegro, Slovakia, Tajikistan, } \\
\text { The former Yugoslav Republic of Macedonia, Turkey, Turkmenistan, Uzbek- } \\
\text { istan }\end{array}$ \\
\hline & Eur-C & Low & High & $\begin{array}{l}\text { Belarus, Estonia, Hungary, Kazakhstan, Latvia, Lithuania, Republic of } \\
\text { Moldova, Russia, Ukraine }\end{array}$ \\
\hline \multirow[t]{2}{*}{$\begin{array}{l}\text { Eastern } \\
\text { Mediterranean }\end{array}$} & Emr-B & Low & Low & $\begin{array}{l}\text { Bahrain, Iran, Jordan, Kuwait, Lebanon, Libyan Arab Jamahiriya, Oman, Qatar, } \\
\text { Saudi Arabia, Syrian Arab Republic, Tunisia, United Arab Emirates }\end{array}$ \\
\hline & Emr-D & High & High & $\begin{array}{l}\text { Afghanistan, Djibouti, Egypt, Iraq, Morocco, Palestinian Territories, Pakistan, } \\
\text { Somalia, Sudan, Yemen }\end{array}$ \\
\hline \multirow[t]{2}{*}{ Western Pacific } & Wpr-A & $\begin{array}{l}\text { Very } \\
\text { low }\end{array}$ & $\begin{array}{l}\text { Very } \\
\text { low }\end{array}$ & Australia, Brunei Darussalam, Japan, New Zealand, Singapore \\
\hline & Wpr-B & Low & Low & $\begin{array}{l}\text { Cambodia, China, Cook Islands, Fiji, French Polynesia, Guam, Hong Kong, } \\
\text { Kiribati, Lao People's Democratic Republic, Macao, Malaysia, Marshall Is- } \\
\text { lands, Pitcairn, Fed. States of Micronesia, Mongolia, Nauru, New Caledonia, } \\
\text { Niue, Norfolk Island, Northern Mariana Islands, Palau, Papua New Guinea, } \\
\text { Philippines, Republic of Korea, Samoa, Solomon Islands, Taiwan, Tokelau, } \\
\text { Tonga, Tuvalu, Vanuatu, Viet Nam, Wallis and Futuna }\end{array}$ \\
\hline
\end{tabular}


Acknowledgements. The research leading to these results has received funding from the European Research Council under the European Union's Seventh Framework Programme (FP7/20072013)/ERC grant agreement no. 226144.

The service charges for this open access publication have been covered by the Max Planck Society.

Edited by: R. Harley

\section{References}

Akimoto H.: Global air quality and pollution, Science, 302, 17161719, 2003.

Amann, M. and Schöpp, W.: Calculation of cause-specific mortality impacts of fine particulate matter in GAINS, CIAM-REPORT 2/2011, International Institute for Applied Systems Analysis, Laxenburg, Austria, 2011.

Anenberg, S. C., Horowitz, L. W., Tong, D. Q., and West, J. J.: An estimate of the global burden of anthropogenic ozone and fine particulate matter on premature human mortality using atmospheric modeling, Environ. Health Perspect., 118, 1189-1195, 2010.

Anenberg, S. C., West, J. J., Horowitz, L. W., and Tong, D. Q.: The global burden of air pollution on mortality, Environ. Health Perspect., 119, 158-159, 2011.

Anenberg, S. C., Schwartz, J., Shindell, D., Amann, M., Faluvegi, G., Klimont, Z., Janssens- Maenhout, G., Pozzoli, L., Van Dingenen, R., Vignati, E., Emberson, L., Muller, N. Z., West, J. J., Williams, M., Demkine, V., Hicks, W. K., Kuylenstierna, J., Raes, F., and Ramanathan, V.: Global air quality and health cobenefits of mitigating near-term climate change through methane and black carbon emission controls, Environ. Health. Perspect., 120, 831-839, 2012.

Astitha, M., Lelieveld, J., Abdel Kader, M., Pozzer, A., and de Meij, A.: Parameterization of dust emissions in the global atmospheric chemistry-climate model EMAC: impact of nudging and soil properties, Atmos. Chem. Phys., 12, 11057-11083, doi:10.5194/acp-12-11057-2012, 2012.

Bell, M. L., McDermott, A., Zeger, S. L., Samet, J. M., and Dominici, F.: Ozone and short-term mortality in 95 US urban communities, 1987-2000, J. Amer. Med. Assoc., 292, 2372-2387, 2004.

Bell, M. L. and Dominici, F.: Effect modification by community characteristics on the short-term effects of ozone exposure and mortality in 98 US communities, Am. J. Epidemiol., 167, 986997, 2008.

Brauer, M., Amann, M., Burnett, R. T., Cohen, A., Dentener, F., Ezzati, M., Henderson, S. B., Krzyzanowski, M., Martin, R. V., Van Dingenen, R., Van Donkelaar, A., and Thurston, G. D.: Exposure assessment for estimation of the Global Burden of Disease attributable to outdoor air pollution, Environ. Sci. Technol., 46, 652-660, 2012.

Brook, R. D., Rajagopalan, S., Pope III, C. A., Brook, J. R., Bhatnagar, A., Diez-Roux, A. V., Holguin., F., Hong, Y., Luepker., R. V., Mittleman, M. A., Peters, A., Siscovick, D., Smith Jr., S. C., Whitsel, L., and Kaufman, J. D.: Particulate matter air pollution and cardiovascular disease - An update to the scientific statement from the American Heart Association, J. Am. Heart Assoc., 121, 2331-2378, 2010.

Brunekreef, B. and Holgate, S. T.: Air pollution and health, The Lancet, 360, 1233-1242, 2002.

Center for International Earth Science Information Network (CIESIN), Columbia University; United Nations Food and Agriculture Programme (FAO) and Centro Internacional de Agricultura Tropical (CIAT): Gridded Population of the World, Version 3 (GPWv3): Population Density Grid, Future Estimates. Palisades, NY: Socioeconomic Data and Applications Center (SEDAC), Columbia University, available from: http://sedac. ciesin.columbia.edu/gpw (last access: March 2011), 2005.

Cohen, A. J., Anderson, H. R., Ostro, B., Pandey, K. D., Krzyzanowski, M., Künzli, N., Gutschmidt, K., Pope, A., Romieu, I., Samet, J. M., and Smith, K.: Urban air pollution, in: Comparative quantification of health risks, Global and regional burden of disease attributable to selected major risk factors, Volume 1, World Health Organization, Geneva, 2004.

Cohen, A. J., Anderson, H. R., Ostro, B., Pandey, K. D., Krzyzanowski, M., Künzli, N., Gutschmidt, K., Pope, A., Romieu, I., Samet, J. M., and Smith, K.: The global burden of disease due to outdoor air pollution, J. Toxicol. Environ. Health, 68, 1-7, 2005.

Committee on the Medical Effects of Air Pollutants (COMEAP): Long-Term Exposure to Air Pollution: Effect on Mortality, Health Protection Agency, UK, ISBN 978-0-85951-640-2, 2009.

Committee on the Medical Effects of Air Pollutants (COMEAP): The mortality effects of long-term exposure to particulate air pollution in the United Kingdom, Health Protection Agency, UK, ISBN 978-0-85951-685-3, 2010.

Crutzen, P. J.: Geology of mankind, Nature, 415, 23, 2002.

De Meij, A., Pozzer, A., Pringle, K. J., Tost, H., and Lelieveld, J.: EMAC model evaluation and analysis of atmospheric aerosol properties and distribution, Atmos. Res., 114-115, 38-69, 2012.

Dockery, D. W., Pope III, C. A., Xu, X., Spengler, J. D., Ware, J. H., Fay, M. E., Ferris, B. G., and Speizer, F. E.: An association between air pollution and mortality in six U.S. cities, N. Engl. J. Med., 329, 1753-1759, 1993.

Doering, U., van Aardenne, J., Monni, S., Pagliari, V., Orlandini, L., and SanMartin, F.: CIRCE report D8.1.2 - Evaluation emission database 1990-2005. Tech. Rep., Project FP6: 6.3, No. 036961, 2009.

Ezzati, M., Lopez, A. D., Rodgers, A., Hoorn, S. V., and Murray, C. J. L: The Comparative Risk Assessment Collaborating Group: Selected major risk factors and global and regional burden of disease, Lancet, 360, 1347-1360, 2002.

Fang, Y., Naik, V., Horowitz, L. W., and Mauzerall, D. L.: Air pollution and associated human mortality: the role of air pollutant emissions, climate change and methane concentration increases from the preindustrial period to present, Atmos. Chem. Phys., 13, 1377-1394, doi:10.5194/acp-13-1377-2013, 2013.

Fann, N., Lamson, A., Anenberg, S. C., Wesson, K., Risley, D., and Hubbell, B. J.: Estimating the national public health burden associated with exposure to ambient $\mathrm{PM}_{2.5}$ and ozone, Risk Analysis, 32, 81-95, 2012.

Franck, U., Odeh, S., Wiedensohler, A., Wehner, B., and Herbarth, O.: The effect of particle size on cardiovascular disorders - The smaller the worse, Sci. Total Environ. 409, 4217-4221, 2011. 
Jerrett, M., Burnett, R. T., Pope III, C. A., Ito, K., Thurston, G., Krewski, D., Shi, Y., Calle, E., and Thun, M.: Long-term ozone exposure and mortality, N. Engl. J. Med., 360, 1085-1095, 2009.

Jöckel, P., Tost, H., Pozzer, A., Brühl, C., Buchholz, J., Ganzeveld, L., Hoor, P., Kerkweg, A., Lawrence, M. G., Sander, R., Steil, B., Stiller, G., Tanarhte, M., Taraborrelli, D., van Aardenne, J., and Lelieveld, J.: The atmospheric chemistry general circulation model ECHAM5/MESSy1: consistent simulation of ozone from the surface to the mesosphere, Atmos. Chem. Phys., 6, 50675104, doi:10.5194/acp-6-5067-2006, 2006.

Krewski, D., Burnett, R. T., Goldberg, M. S., Hoover, K., Siemiatycki, J., Abrahamowicz, M., and White, W. H.: Part I: Replication and Validation. In: Reanalysis of the Harvard Six Cities Study and the American Cancer Society Study of Particulate Air Pollution and Mortality. A Special Report of the Institute's Particle Epidemiology Reanalysis Project, Health Effects Institute, Cambridge, MA, 2000a.

Krewski, D., Burnett, R. T., Goldberg, M. S., Hoover, K., Siemiatycki, J., Jerrett, M., Abrahamowicz, M., and White, W. H.: Part II. Sensitivity Analysis. In: Reanalysis of the Harvard Six Cities Study and the American Cancer Society Study of Particulate Air Pollution and Mortality. A Special Report of the Institute's Particle Epidemiology Reanalysis Project, Health Effects Institute, Cambridge, MA, 2000b.

Krewski, D., Jerrett, M., Burnett, R. T., Ma, R., Hughes, E., Shi, Y., Turner, M. C., Pope III, C. A., Thurston, G., Calle, E. E., and Thun, M. J.: Extended follow-up and spatial analysis of the American Cancer Society Study linking particulate air pollution and mortality, Health Effects Institute, Boston, MA, 2009.

Laden, F., Schwarz, J., Speizer, F. E., and Dockery, D. W.: Reduction in fine particulate air pollution and mortality, Am. J. Resp. Crit. Care. Med., 173, 667-672, 2006.

Lelieveld, J. and Dentener, F. J.: What controls tropospheric ozone?, J. Geophys. Res., 105, 3531-3551, 2000.

Lepeule, J., Laden, F., Dockery, D., and Schwartz. J.: Chronic exposure to fine particles and mortality: An extended follow-up of the Harvard Six Cities Study from 1974-2009, Environ. Health Perspect., 120, 965-970, 2012.

Lim, S. S., Vos, T., Flaxman, A. D., Danaei, G., and Shibuya, K.: A comparative risk assessment of burden of disease and injury attributable to 67 risk factors and risk factor clusters in 21 regions, 1990-2010: a systematic analysis for the Global Burden of Disease Study 2010, Lancet, 380, 2224-2260, 2012.

Ostro, B.: Outdoor air pollution: assessing the environmental burden of disease at national and local levels, World Health Organization (WHO) Environmental Burden of Disease Series No. 5, 2004.

Pelucchi, C., Negri, E., Gallus, S., Boffetta, P., Tramacere, I., and La Vecchia, C.: Long-term particulate matter exposure and mortality: a review of European epidemiological studies, BMC Public Health, 9, 453, doi:10.1186/1471-2458-9-453, 2009.

Pope III, C. A., Thun, M. J., Namboodiri, M. M., Dockery, D. W., Evans, J. S., Speizer, F. E., and Heath, C. W.: Particulate air pollution as a predictor of mortality in a prospective study of U.S. adults, Am. J. Respir. Crit. Care Med., 151, 669-674, 1995.

Pope III, C. A., Burnett, R. T., Thun, M. J., Calle, E. E., Krewski, D., Ito, K., and Thurston, G. D.: Lung cancer, cardiopulmonary mortality, and long-term exposure to fine particulate air pollution, J. Am. Med. Assoc., 287, 1132-1141, 2002.
Pope III, C.-A., Ezzati, M., and Dockery, D. W.: Fine-particulate air pollution and life expectancy in the United States, N. Engl. J. Med., 360, 376-386, 2009.

Pozzer, A., Zimmermann, P., Doering, U.M., van Aardenne, J., Tost, H., Dentener, F., Janssens-Maenhout, G., and Lelieveld, J.: Effects of business-as-usual anthropogenic emissions on air quality, Atmos. Chem. Phys., 12, 6915-6937, doi:10.5194/acp-12-69152012, 2012a.

Pozzer, A., de Meij, A., Pringle, K. J., Tost, H., Doering, U. M., van Aardenne, J., and Lelieveld, J.: Distributions and regional budgets of aerosols and their precursors simulated with the EMAC chemistry-climate model, Atmos. Chem. Phys., 12, 961-987, doi:10.5194/acp-12-961-2012, 2012 b.

Pringle, K. J., Tost, H., Message, S., Steil, B., Giannadaki, D., Nenes, A., Fountoukis, C., Stier, P., Vignati, E., and Lelieveld, J.: Description and evaluation of GMXe: a new aerosol submodel for global simulations (v1), Geosci. Model Dev., 3, 391-412, doi:10.5194/gmd-3-391-2010, 2010.

Pruett, R. L. and Goodman. J. E.: The global burden of ozone on respiratory mortality: no clear evidence for association, Environ. Health Perspect., 119, 158, 2011.

Prüss-Üstün, A., Bonjour, S., and Corvalan, C.: The impact of the environment on health by country: a meta-synthesis, Environ. Health, 7, 7, doi:10.1186/1476-069X-7-7, 2008.

Punger, E. M. and West, J. J.: The effect of grid resolution on estimates on the burden of ozone and fine particulate matter on premature mortality in the USA, Air Qual. Atmos. Health, doi:10.1007/s11869-013-0197-8, 2013.

Roman, H. A., Walker, K. D., Walsh, T. L., Conner, L., Richmond, H. M., Hubbell, B. J., and Kinney, P. L.: Expert judgment assessment of the mortality impact of changes in ambient fine particulate matter in the U.S., Environ. Sci. Technol., 42, 2268-2274, 2008.

Saikawa, E., Naik, V., Horowitz, L. W., Liu, J., and Mauzerall, D. L.: Present and potential future contributions of sulfate, black and organic carbon aerosols from China to global air quality, premature mortality and radiative forcing, Atmos. Environ., 43, 28142822, 2009.

Samet, J. M., Dominici, F., Curriero, F. C., Coursac, I., and Seger, S. L.: Fine particulate air pollution and mortality in 20 U.S. cities, 1987-1994, New Eng. J. Med., 343, 1742-1749, 2000.

Samoli, E., Peng, R., Ramsay, T., Pipikou, M., Touloumi, G., Dominici, F., Burnett, R., Cohen, A., Krewski, D., Samet, J., and Katsouyanni, K.: Acute effects of ambient particulate matter on mortality in Europe and North America: results from the APHENA study, Environ. Health Perspect., 116, 1480-1486, 2008.

Sokhi, R. S. (Ed.): World atlas of atmospheric pollution, Anthem Press, London, 2011.

Solomon, P. A., Wexler, A. S., and Sioutas, C.: Special issue of Atmospheric Environment for air pollution and health: Bridging the gap from sources-to-health outcomes, Atmos. Environ., 45, 7537-7539, 2011.

United Nations Department of Economic and Social Affairs (UNDES), Population Division: World Population Prospects: the 2010 Revision, available at: http://esa.un.org/unpd/wpp (last update: 28 June 2011), 2011.

Van Donkelaar, A., Martin, R. V., Brauer, M., Kahn, R., Levy, R., Verduzco, C., and Villeneuve, P. J.: Global estimates of am- 
bient fine particulate matter concentrations from satellite-based aerosol optical depth: Development and application, Environ. Health Perspec., 118, 847-855, 2010.

Wang, X. and Mauzerall, D. L.: Evaluating impacts of air pollution in China on public health: Implications for future air pollution and energy policies, Atmos. Environ., 40, 1706-1721, 2006.

West, J. J., Fiore, A. M., Horowitz, L. W., and Mauzerall, D. L.: Global health benefits of mitigating ozone pollution with methane emission controls, P. Natl. Acad. Sci. USA, 103, 39883993, 2006.

WHO (World Health Organization): The world health report 2002: reducing risks, promoting healthy life. WHO, Geneva, available at: http://www.who.int/whr/2002/en/ (last access: June 2010), 2002.
WHO (World Health Organization): The global burden of disease: 2004 update, WHO, Geneva, available at: http://www.who.int/healthinfo/global_burden_disease/ estimates_regional/en/index.html [accessed 16 December 2011], 2008.

WHO (World Health Organization): World Health Organization Statistical Information System (WHOSIS), Detailed Data Files of the WHO Mortality Database, WHO, Geneva, available at: http://www.who.int/whosis/mort/download/en/index.html (last access: July 2012), 2012. 